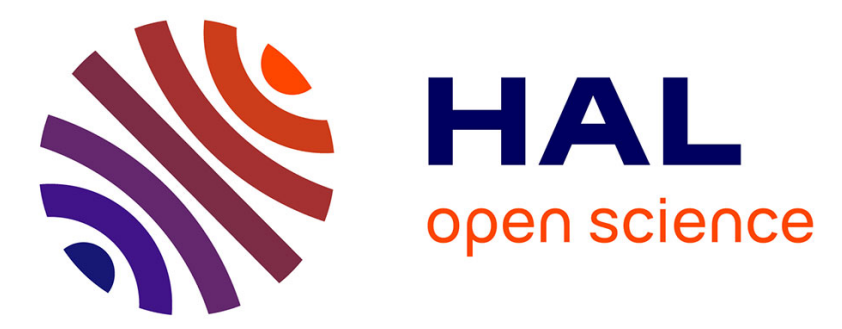

\title{
The tandem accelerator EGP-10-1 of the Central Institute of Nuclear Research at Rossendorf
}

\author{
H. Matthes, R. Weibrecht
}

\section{To cite this version:}

H. Matthes, R. Weibrecht. The tandem accelerator EGP-10-1 of the Central Institute of Nuclear Research at Rossendorf. Revue de Physique Appliquée, 1977, 12 (10), pp.1327-1329. 10.1051/rphysap:0197700120100132700 . jpa-00244317

\section{HAL Id: jpa-00244317 https://hal.science/jpa-00244317}

Submitted on 1 Jan 1977

HAL is a multi-disciplinary open access archive for the deposit and dissemination of scientific research documents, whether they are published or not. The documents may come from teaching and research institutions in France or abroad, or from public or private research centers.
L'archive ouverte pluridisciplinaire HAL, est destinée au dépôt et à la diffusion de documents scientifiques de niveau recherche, publiés ou non, émanant des établissements d'enseignement et de recherche français ou étrangers, des laboratoires publics ou privés. 


\title{
THE TANDEM ACCELERATOR EGP-10-1 OF THE CENTRAL INSTITUTE OF NUCLEAR RESEARCH AT ROSSENDORF
}

\author{
H. MATTHES and R. WEIBRECHT \\ Academy of Science of the GDR, \\ Central Institute of Nuclear Research at Rossendorf, dept. G \\ Rossendarf, 805 Dresden, Postfach 19, G.D.R.
}

\begin{abstract}
Résumé. - On donne les paramètres fondamentaux de l'accélérateur tandem EGP $-10-1$ ainsi que des spécifications techniques. L'équipement supplémentaire est décrit. Ensuite on rapporte le travail de développement effectué en vue de l'augmentation de la fiabilité du fonctionnement et sur l'extension des possibilités expérimentales. Les résultats de l'opération et l'exploitation sont discutés.

Abstract. - In the paper the basic physical parameters of the tandem accelerator EGP $-10-1$ are given and technical specifications and additional equipments described. Further more it is reported upon development work for improvement of running reliability and upon extension of experimental possibilities. Results of operation and utilization are discussed.
\end{abstract}

1. Layout and basic parameters. - The tandemgenerator EGP-10-1, termed TG in the following, belongs to the class of small type machines. A detailed description of the TG was given by Hochberg et $a l$. [1]. The TG was developed and built at the D.V. Efremov Scientific Research Institute of Electrophysical Apparatus at Leningrad. It is designed for the acceleration of protons and deuterons. The range of terminal-voltage is 0.9 up to $5 \mathrm{MV}$. At the target a maximum intensity of protons of $2 \times 10^{13} \mathrm{p} / \mathrm{s}$ is obtained. The long term stability during $6 \mathrm{~h}$ is $\pm 170 \mathrm{eV}$ at a proton energy of $6 \mathrm{MeV}$ [2]. The cross-section of the beam on the target is about $2 \times 4 \mathrm{~mm}^{2}$. The TG is set up in a vertical position. A duoplasmatron ion source with direct negative ion extraction is used. Figure 1 shows the general layout of the TG with its characteristic elements : a bilateral $90^{\circ}$ inflecting magnet, inclined field tubes with stainless steel electrodes, differential pumping tube for pumping the stripper gas, a bilateral $90^{\circ}$ analyzing magnet, two switching magnets, beam lines with 10 target sites and the pressure vessel. The insulating gas which we use consists of a mixture of nitrogen, carbondioxid and freon. The operating pressure is 14 bar. In an experiment we achieved a terminal-voltage of 7.3 MV without accelerating tubes. Figure 2 gives a survey of the column structure of the TG.

2. Development work and results of utilization. Since the TG has been put into operation on november 2, 1972 work has consistently been directed at enhancing experimental facilities and increasing the reliability. Already since 1974 nitrogen ions have been

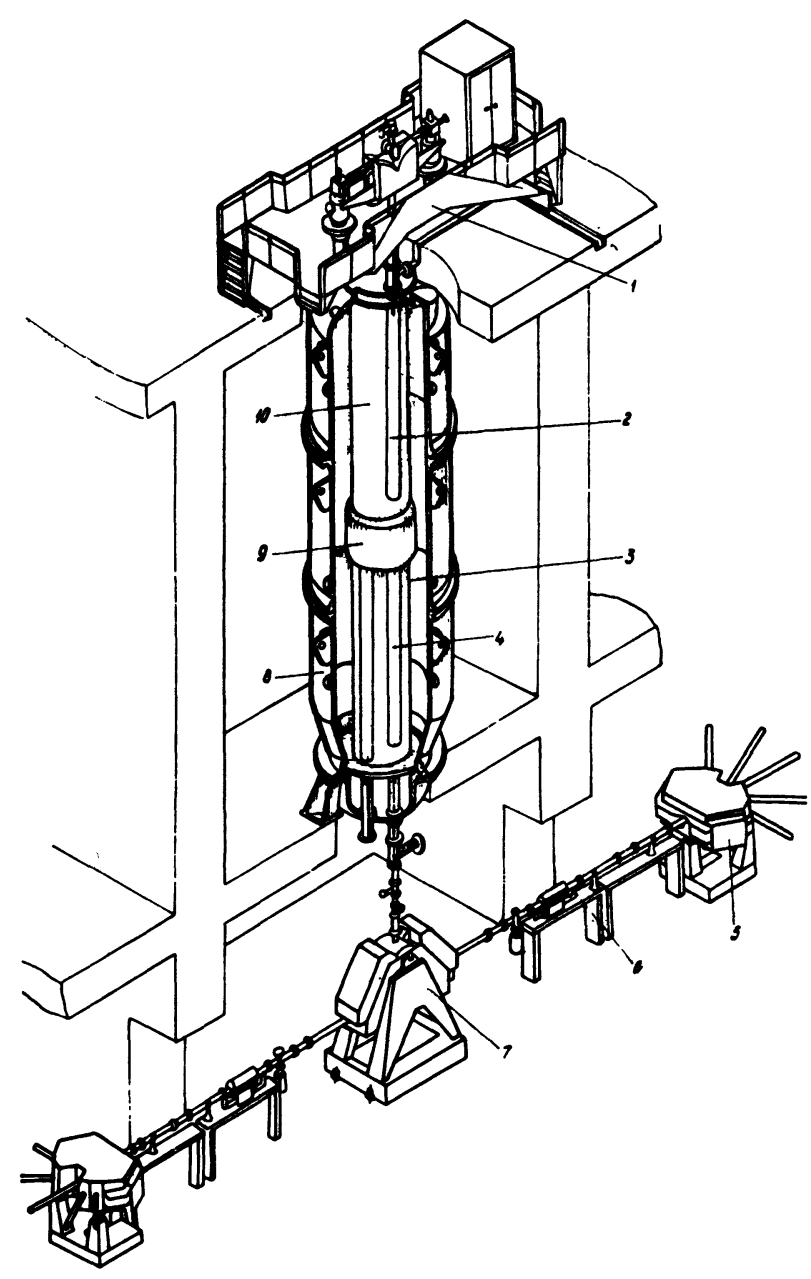

FIG. 1. - Layout of the Tandem accelerator EGP-10-1. 


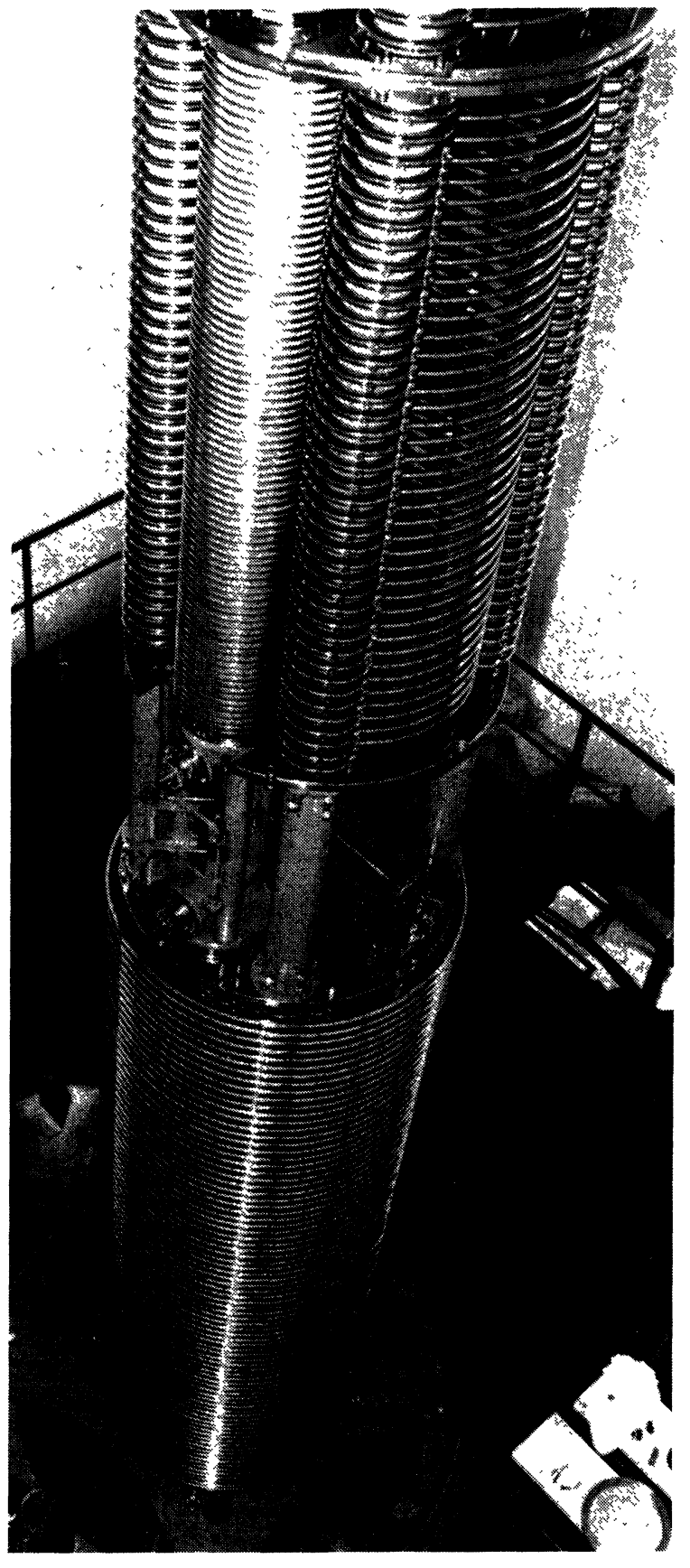

FIG. 2. - The columne structure of the EGP-10-1.

accelerated routinely. In 1976, the accelerated species of ions were extended to ions of carbon and bromine. For this ions the duoplasmatron ion source is also used [3]. A current of negative ions $\left(\mathrm{NH}_{2}{ }^{-}\right)$up to $1.5 \mu \mathrm{A}$ and $\left(\mathrm{CN}^{-}\right)$up to $10 \mu \mathrm{A}$ can be obtained, respectively. In this case the cathode lifetime averages $440 \mathrm{~h}$. For producing negative bromine ions pure ethyl bromide is fed into the ion source. It is necessary to ignite the discharge of the ion source with hydrogen. The ion source provides a negative bromine ion current up to $3 \mu \mathrm{A}$. At present the average cathode lifetime is still unsatisfactory.

The acceleration of heavy ions with the inclined field tube was practically infeasible because the ion beam parameters were unsatisfactory. Calculation of trajectories showed, that fivefold charged ions of nitrogen in the high-energy tube are so much deflected that they hit the electrodes [4]. For lack of a terminal steerer the trajectory of ions behind the stripper was corrected by short circuiting two electrodes of the high-energy tube. Figure 3 shows the trajectories of the accelerated ions in the high-energy tube without and with short circuiting two electrodes, respectively. Thus the acceleration of manyfold charged ions by the TG has been considerably improved. Figure 4 gives a survey of the operating time distribution of ion species at the TG for the last year.

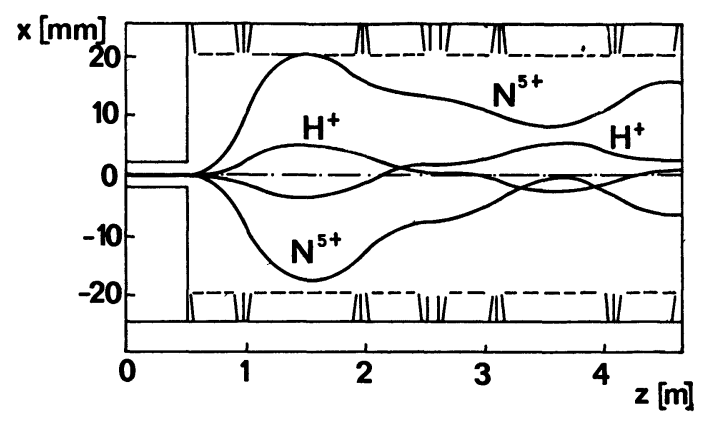

FIG. 3. - Trajectories of axial rays through the high-energy accelerating tube of the EGP-10-1.

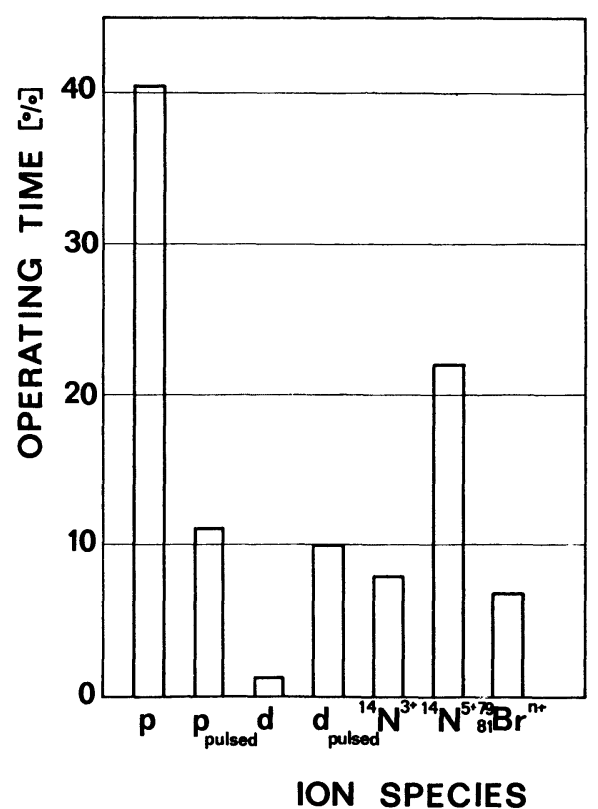

FIG. 4. - Operating time distribution of ion species at the EGP-10-1 in 1976 .

In 1974 an annular pick-up electrode was built into the accelerator [5]. An extension of the experimental facilities was achieved by building in bunching device [6]. In the energy region 4 up to $9 \mathrm{MeV}$ an impulse width of $(2.5 \pm 1) \mathrm{ns}$ is reached at an impulse distance of $200 \mathrm{~ns}$.

Considerable effort has been spent on the permanent enhancement of the TG's operational reliability. As 
a result it was possible to increase the average lifetime of the belts up to $1050 \mathrm{~h}$ (1976).

In the years $74 / 75$ the pressure vessel of the TG had to be opend 18 times because defective column resistors. On the basis of a resistor type produced - the GDR a resistor network was developed (Fig. 5). The newly developed resistor network has been in operation in the low-energy column for one year without any failures.

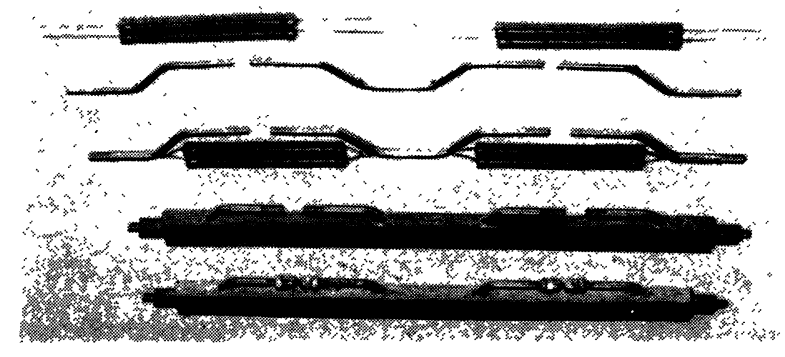

FIG. 5. - Resistor network.

The completion of the gas handling system has essentially contributed to enhancing the operational reliability and diminishing operation costs of the TG.

An extensive investigation into the application of turbomolecularpumps of the type TMN-200 produced in the Soviet Union was carried out with a positive result [7]. On this basis, work was started on the reconstruction of the vacuum system of the TG with a view to replacing the mercury diffusion pumps by a combination turbomolecularpumps TMN-200/ titanium sputter pumps EGZ 500 (VEB HVD Dresden, G.D.R.).

Both continuous qualification of operational staff and the technical measures taken have considerably contributed to stabilizing the operation and enhancing operational reliability. Figure 6 shows the efficiency of these measures and activities. These results are based on three-shift working time, 5 workdays per week.

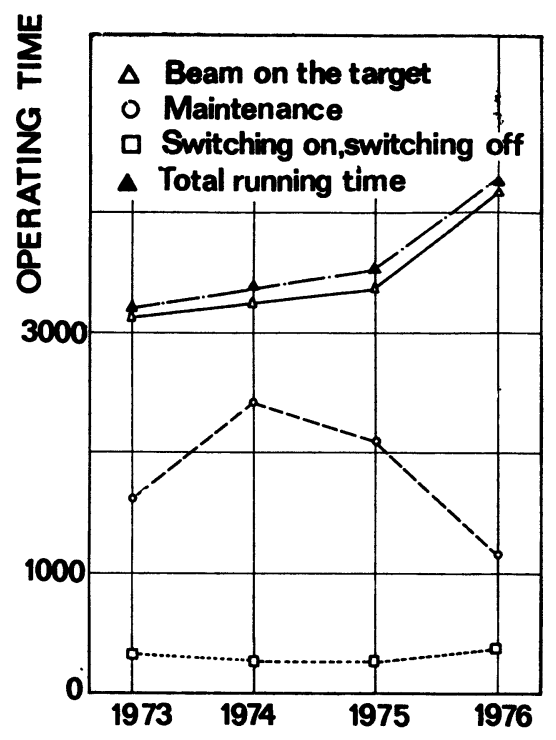

FIG. 6. - Operational results at the EGP-10-1, 1973-1976.

\section{References}

[1] HOCHBERg B. M., et al., Nucl. Instrum Methods 122 (1974) 118

[2] WeibRecht R., et al., Isotopenpraxis 12 (1976) 97.

[3] Matthes H., Steinert L., ZfK-262 (1973).

[4] FRIEDRICH M., GunZel R. (paper is submitted for publication in PTE).

[5] Curian H., Siergert W., ZfK G 13/75.

[6] ECKSTEIN P., et al., ZfK-283 (1974).

[7] Pfestorf W., ZfK G 21/75. 